ROCZNIKI HUMANISTYYCZNE

Tom LXVII, zeszyt 6 - 2019

DOI: http://dx.doi.org/10.18290/rh.2019.67.6-3

\title{
ANNA CEGIEŁA
}

\section{NA JAKICH PODSTAWACH NAUKOWYCH OPIERA SIE ETYKA SŁOWA?}

Zdajemy sobie sprawe, że istotnym znakiem cywilizacji, która zastuguje na to imie, jest zrozumienie i szacunek dla godności osoby ludzkiej.

Jacques Maritain

Zajmujący się etyką słowa niejednokrotnie znajdują się w dość kłopotliwym położeniu. Przedstawiają zasady poszanowania drugiego człowieka, zachowania jego podmiotowości i autonomiczności i obok słów akceptacji swojej wypowiedzi słyszą np. od dziennikarzy, że dzięki konfrontacyjnemu formatowi audycji i emocjonalnemu zachowaniu ich uczestników wzrasta poziom oglądalności programów. W ten sposób etyka komunikacji zostaje przeciwstawiona praktyce, co ma udowodnić, że jest zbiorem pięknych, ale nieżyciowych postulatów i co najwyżej przedmiotem zainteresowania oderwanych od rzeczywistości naukowców. Innymi słowy, to komunikacja pełna agresji, manipulacji i kłamstwa jest działaniem rozumnym, a nadto niewymagającym uzasadnienia, bo łatwo dostrzec jej skuteczność, a nie refleksja nad moralnością, bo przecież rezultatów tej drugiej nie widać.

Nie podejmuję się przekonania dziennikarzy, polityków, specjalistów od marketingu oraz innych ludzi niedostrzegających zagrożeń tkwiących w nieetycznej komunikacji do zmiany postawy. Spróbuję jednak pokazać, gdzie można szukać racjonalnego uzasadnienia etyki słowa rozumianej jako inter-

Dr hab. ANNA CEGIEŁA - adiunkt Zakładu Edytorstwa i Stylistyki Instytutu Polonistyki Stosowanej UW, kierownik „Obserwatorium etyki słowa”; adres do korespondencji: Uniwersytet Warszawski, Krakowskie Przedmieście 26/28, 00-927 Warszawa; e-mail: ceganster@gmail.com 
dyscyplinarna dziedzina nauki oraz działalność poprawiająca międzyludzką komunikację.

Etyka słowa powstała z potrzeby i z konieczności. Z potrzeby zrozumienia mechanizmów językowych, których skutkiem było zniewolenie umysłowe ludzi w systemach zamkniętych - III Rzeszy i krajach obozu tzw. demokracji ludowej, pisali Victor Klemeperer i Alain Besançon, Andrzej Bogusławski i Jerzy Bralczyk. Z konieczności przeciwstawienia się wpływom mówienia przeciw człowiekowi wypowiadali się Michał Głowiński, Jadwiga Puzynina, Irena Kamińska-Szmaj, Elżbieta Laskowska, Françoise Thom. A po nich o władzy nad mową mówiło wielu badaczy, których teksty zamieszczono w lubelskiej antologii Etyka słowa ${ }^{1}$. Tylko kilku z nich posługiwało się tym określeniem, bo język używany jako narzędzie władzy i manipulacji opisywano z różnych innych perspektyw - językoznawstwa, retoryki, teorii literatury, nauki o mediach i o polityce. Obiektem opisu w takich badaniach długi czas było samo użycie języka, a nie jego użytkownik. Od początku jednak w analizach języka pojawiał się problem prawdy i władzy nad słowem, do której sprawowania nikt nie dawał prawa, a która naruszała podmiotowość człowieka i granice ludzkiej wolności. Od czasu, kiedy tematykę tę podejmowano, istniała zatem etyka słowa - w pewnym sensie jako interdyscyplinarna dziedzina humanistyki. Gdy przedmiotem badań były sposoby sprawowania władzy za pomocą języka, bardziej zbliżała się ona do politologii, gdy analizowano mechanizmy perswazji, bliższa stawała się retoryce, gdy opisywano zabiegi językowe, właściwie należała do językoznawstwa. Dziś, gdy ma już ustabilizowaną nazwę i pozycję w humanistyce, najściślej łączy się z filozofią oraz socjologią i na dorobku tych dziedzin się opiera. O teoretycznych podstawach filozoficznych i socjologicznych etyki słowa będzie mowa w tym artykule.

Przede wszystkim trzeba pamiętać, że chociaż posługujemy się terminem etyka słowa, w gruncie rzeczy mamy na myśli komunikację, a więc także gesty, mimikę, obraz, a nawet dźwięk, czyli wszystko to, co jest nośnikiem treści i wpływa na jej rozumienie oraz oddziaływanie. Jako że komunikacja - to kontakt z kimś, że odbywa się w przestrzeni społecznej, za jej komponenty musimy uznać także uczestników komunikacji, okoliczności przekazu, audytorium, zasięg oddziaływania treści i kilka innych czynników. Wszystkie

\footnotetext{
${ }^{1}$ Etyka stowa. Wybór opracowań, t. 1, red. J. Bartmiński, S. Niebrzegowska-Bartmińska, M. Nowosad-Bakalarczyk, J. Puzynina, Lublin: Wydawnictwo Uniwersytetu Marii Curie-Skłodowskiej 2017. Nie wszystkie teksty w tej antologii mieszczą się w zakresie etyki słowa, ale wszystkie jej dotyczą.
} 
one mają wpływ na społeczny skutek komunikacji. Komunikacja jest działaniem, ma wymiar moralny i społeczny, choć myślenie potoczne redukuje ją zwykle do kwestii językowych i utożsamia z umiejętnością posługiwania się narzędziem.

Etyka słowa postrzega ją nieco inaczej - jako spotkanie z drugim człowiekiem. Tak też widzą ją wielcy filozofowie i to ich koncepcje dostarczają podstawowych uzasadnień dla tej dziedziny nauki ${ }^{2}$. Konieczne jest tu wszakże jedno ważne zastrzeżenie, a mianowicie, że wobec coraz bardziej skomplikowanych problemów moralnych współczesnego świata wielu filozofów jest bezradnych, nie możemy zatem opierać się na dowolnej doktrynie etycznej, lecz tylko na takiej, która jest racjonalna, spójna i dostarcza przekonujących uzasadnień. Najważniejsze $\mathrm{z}$ nich to odpowiedzi na fundamentalne dla etyki pytania - dlaczego i wobec kogo mamy zobowiązania moralne i dlaczego norma moralna powinna być normą społeczną, czyli obowiązywać wszystkich, a więc także uczestników komunikacji?

W czasach, kiedy skuteczność stała się wręcz obsesją homo fabera, zadowalająca odpowiedź na te dwa pytania jest niezwykle trudna i nie dają jej największe systemy filozoficzne. Zjawiskiem, które bardzo komplikuje formułowanie norm moralnych i ich uzasadnianie, jest także charakterystyczny dla naszych czasów brak poczucia bezpieczeństwa i brak rzetelnego rozeznania etycznego, co powoduje chęć obrony przed różnymi zagrożeniami i swoistą presję na państwo, aby różne szczegółowe zasady moralne sankcjonowało prawnie. Skutki tej presji nie zawsze są społecznie korzystne, a przepisy bywają przedmiotem sporów dzielących społeczeństwo ${ }^{3}$. Pytanie o obowiązywanie norm jest bowiem z jednej strony pytaniem o dobro przez nie chronione, z drugiej zaś - o sankcje w razie ich naruszenia. Spory toczą się właśnie o różne rozumienie dobra oraz o sankcje. Jeśli norma jest zbyt szczegółowa, zachodzi obawa, że dobro przez nią chronione jest partykularne. Jeśli sankcja jest dotkliwa, można uznać, że nie chodzi o wartość (np. troskę o człowieka), lecz o wyróżnienie i wzmocnienie grupy przez szczególną ochronę. Sankcjonowanie pewnych norm, także norm komunikacji, ma dać gwarancję, że nie dotknie nas krzywda, ale często przynosi nieplanowane rezultaty - zachowa-

\footnotetext{
${ }^{2} \mathrm{~W}$ tym tekście nie powołuję się na filozofów dialogu, gdyż nie jest to konieczne, ale to oni (Martin Buber, Emmanuel Levinas, Józef Tischner) najpiękniej i głęboko piszą o spotkaniu Drugiego Człowieka.

${ }^{3}$ Przykładami takich uregulowań prawnych, które wywołują spory i przynoszą niewielkie korzyści, jest ustawa o mowie nienawiści.
} 
nia zagrożone sankcjami stają się częstsze, a przepisy wykorzystuje się do niszczenia przeciwników.

Dla rozważań o etyce komunikacji jest ważny fakt, że istnieje racjonalna odpowiedź na pytanie o to, wobec kogo mamy być moralni. Daje ją filozofia personalistyczna i zrodzona na jej gruncie koncepcja człowieka jako osoby. Koncepcja ta miała doniosły wpływ na formułowanie praw człowieka w dwudziestowiecznej Europie. Jej istota jest wprowadzenie przez Jacques'a Maritaina ważnego rozróżnienia między osobą a jednostką. Jednostka jest zdaniem filozofa jedynie częścią zbiorowości, osoba zaś wszechświatem o naturze rozumnej, bytem jedynym i niepowtarzalnym, obdarzonym wolnością wyboru, autonomicznym wobec świata ${ }^{4}$. Takie rozumienie osoby u Maritaina miało genezę religijną. Zasadniczo jednak jest ono obecne w tym samym rozumieniu w całej filozofii personalistycznej, w antropologii oraz we współczesnej psychologii humanistycznej już bez religijnych umocowań. Mówi się zatem (zależnie od perspektywy badawczej) o podmiotowości człowieka, która oznacza, że jest on bytem rozumnym, suwerennym, świadomym siebie, mającym tożsamość, własny system wartości, na którym opiera swoje wybory, niepowtarzalnym, poznającym, doświadczającym. Jako byt podmiotowy człowiek ma godność. Gnoseologia uwypukla jego świadomość, ontologia - suwerenność, psychologia - indywidualność. Podmiotowość człowieka jest zatem kategorią filozoficzną, antropologiczną, psychologiczną oraz prawną. To ona stanowi podstawę praw przyznawanych człowiekowi w deklaracjach i konstytucjach, o czym będzie mowa w dalszej części tekstu. Przyznanie, że człowiek jest osobą, czyli ma podmiotowość, oznacza, że jego ludzkiej godności należy się poszanowanie w każdym działaniu ku niemu skierowanym. Jest ona bowiem wartością podstawową, z której inne (np. wolność) zostają wywiedzione. W odniesieniu do komunikacji wyraża się to w zasadach poszanowania jego wymiaru osobowego (niedehumanizowaniu), uwzględnianiu jego tożsamości, wielowymiarowości (indywidualności) oraz suwerenności.

Uznanie osobowego charakteru człowieka lub mówiąc inaczej - jego podmiotowości, ma ważne konsekwencje w myśleniu o jego roli i miejscu w życiu społecznym. To jemu, a nie klasie, warstwie, rasie, narodowi, firmie czy innym kategoriom zbiorowym przyznaje wartość najwyższą w otaczającym nas świecie. Stąd właśnie bierze się stanowisko personalistyczne w odniesieniu do życia społecznego: struktury zbiorowe uznaje się za służebne wobec

\footnotetext{
${ }^{4}$ Dla Maritaina człowiek jest imago Dei, co ma oczywiście źródło religijne. Do rozważań o etyce takie pojmowanie osoby nie jest niezbędne.
} 
rozwoju osobowego człowieka w społeczeństwie. Człowiek pojmowany jako osoba nie jest narzędziem ani środkiem, lecz bytem autonomicznym. Ma niezbywalne prawo do odkrywania i realizowania własnego powołania, własnej drogi życiowej, co wymaga działania świadomego, wolnego, a nie narzuconego przez warunki zewnętrzne. Dlatego wszystkie normy, które się do niego odnoszą, w tym normy komunikacji, powinny być zachowywane bez względu na interesy różnego typu organizacji (partii, narodu, przedsiębiorstwa, klasy społecznej), a więc również bez względu na poziom oglądalności, popularność ośrodka medialnego, wielkość sprzedaży produktów itp.

Jest także istotą społeczną, więc potrzebuje społeczeństwa i jest od niego zależny. Podporządkowanie człowieka społeczeństwu wynika jednak nie z nakazów zewnętrznych, lecz z uznania wspólnego dobra zbiorowości i wiąże się z przyjęciem odpowiedzialności za sprawy ponadjednostkowe, pozaosobiste. Tu widać zasadniczą różnicę między odpowiedzialnością i zobowiązaniem osoby od zobowiązania indywidualistycznego jednostki. To drugie jest pojmowane jako konieczność, nienaturalne, narzucone jednostce przez sztuczny, zewnętrzny twór, jakim jest zbiorowość/społeczeństwo. Jednostka (np. w filozofii utylitarystycznej i kontraktualistycznej, a także indywidualistycznej) jest zobowiązaniami obciążona lub przystaje na nie ze względu na własny interes i tym samym znajduje się w sytuacji konfliktu między obowiązkiem wobec społeczeństwa a własną wolnością. Dlatego też bywa we wspólnocie ludzkiej pasażerem na gapę. Wolność osoby jest wolnością do zobowiązania wobec drugiego człowieka/ludzi, do odpowiedzialności, a nie wolnością od takich zobowiązań. W komunikacji - to zobowiązanie do takiego zachowania, które pozwala drugiemu człowiekowi zachować godność i tożsamość oraz daje wybór.

Dlaczego jednak mielibyśmy takie zobowiązania podejmować? Dlaczego mielibyśmy podporządkowywać się jakimkolwiek normom moralnym? Uzasadnienia takiego podporządkowania można szukać zarówno u personalistów, jak u moralistów i komunitarystów, a także poza tymi nurtami, w psychologii i socjologii. Przekonujące uzasadnienie znajduje się w pracach niemieckiego moralisty, Ernsta Tugendhata ${ }^{5}$. Filozof ten twierdzi, że bycie członkiem wspólnoty - to istotny element tożsamości człowieka. Bycie dobrym członkiem wspólnoty stanowi o jego wartości. Bycia członkiem wspólnoty uczymy się podczas procesu socjalizacji, który jest jednocześnie procesem morali-

\footnotetext{
${ }^{5}$ E. Tugendhat, Wykłady o etyce, przełożył J. Sidorek, Warszawa: Oficyna Naukowa
} 2004. 
zacji $^{6}$. Człowieka wiernego zasadom moralnym uznajemy za zasługującego na szacunek, za dobrego członka wspólnoty. Ten zaś człowiek, który zawodzi jako członek wspólnoty, odczuwa moralny wstyd i nie obdarza się go szacunkiem. Zdolność do wstydu zostaje przez Ernsta Tugendhata uznana za uczucie moralne, za swoisty sprawdzian pojmowania siebie samego za istotę moralną, która chce być dobrym członkiem wspólnoty i zasługiwać na szacunek będący miarą naszego dobrego z nią związku ${ }^{7}$. Bycie dobrym członkiem wspólnoty oznacza u filozofa bycie dobrym człowiekiem.

Z uznania przynależności do wspólnoty za ważny aspekt tożsamości wynika uznanie praw wszystkich członków wspólnoty. Wspólnota moralna musi obejmować wszystkich, gdyż nie ma racji, dla której mogłoby być inaczej. W taki sposób przyjmujemy zobowiązanie moralne, a także prawo do wymagania od każdego członka wspólnoty respektowania zasad moralnych. Uznanie, że normy moralne obowiązują wszystkich i należy je stosować wobec każdego człowieka - to wystarczające i racjonalne uzasadnienie moralności w ogóle, a tym samym moralności w komunikacji. Warto zauważyć, że taka koncepcja etyczna spaja moralność osoby i moralność społeczną w jedno, co ją korzystnie odróżnia od wielu innych sposobów ujmowania moralności.

$\mathrm{Z}$ tego skrótowo przedstawionego wywodu filozofa wynika bardzo wiele. Przede wszystkim konieczność rozumienia wartości składających się na to, co nazywamy dobrem wspólnym i chronienia ich, bo to oznacza dbałość o wspólnotę. Myśl tę zresztą odnajdujemy także u komunitarystów. W komunikacji wartości powinny się ujawniać, klarować, ale nie unieważniać i zanikać. Zawsze było sprawą dyskusyjną, czy człowiek wartości tworzy, czy tylko rozpoznaje. Tym problemem współczesna filozofia, a także socjologia moralności zajmują się dziś mniej. Istotne dla etyki komunikacji wydaje się inne zjawisko, o którym piszą uczeni, a mianowicie przemieszczanie się wartości i zmiana ich znaczenia dla ładu społecznego. W przestrzeni publicznej w instytucjach życia społecznego ten proces ujawnia się w sposób niekorzystny dla wspólnoty - w zjawiskach instrumentalizacji wartości, unieważniania ich, podważania albo narzucania i co najbardziej szkodliwe - na traktowaniu samego człowieka jako wymiennego i sfunkcjonalizowanego elemen-

\footnotetext{
${ }^{6}$ Ta myśl pojawia się wcześniej w pracach E. Durkheima i L. Kolhberga.

${ }^{7} \mathrm{~W}$ analogicznej sytuacji Maria Ossowska rozróżnia dwa uczucia moralne: przykrość, w wypadku, gdy się komuś przysporzyło cierpienia, oraz wstyd, gdy naruszyło się czyjąś godność. Ernst Tugendhat łączy oba uczucia i określa je mianem wstydu centralnego. Argumentuje to chęcią uniknięcia problemu z użyciem określenia poczucie winy. M. Ossowska uznaje wstyd i przykrość za składniki poczucia winy.
} 
tu jakiejś organizacji. Spory aksjologiczne, które są zjawiskiem normalnym i potrzebnym, bo dzięki nim kształtują się przekonania i normy moralne, są ideologizowane i upolityczniane, co odbiera im funkcję wspólnototwórczą i powoduje wiele innych zagrożeń. $\mathrm{W}$ takiej właśnie sytuacji rodzi się potrzeba czy wręcz konieczność działań badawczych i naprawczych w zakresie etyki komunikacji. Dobra komunikacja może wspólnotę spajać i wspierać procesy uzgadniania norm będących podstawa ładu społecznego.

Jeśli określi się etykę słowa/komunikacji jako dziedzinę badającą i opisującą sposób posługiwania się językiem (a także obrazem, gestem itd.) w jego relacji do przyjętych przez społeczeństwo wartości oraz ustalaniem norm użycia słowa, które sprzyjają ochronie tych wartości, trzeba również określić warunki takich badań.

Pierwszym trudnym problemem, który się z tym wiąże, jest ustalenie (wykrycie) kanonu wartości dla nas wspólnych. Zakładamy, że taki istnieje, albo że istnieje jakieś minimum aksjologiczne, ale wskazanie takiego zbioru staje się coraz trudniejsze. Dyskusyjne jest już samo określenie kanonu wartości - czy oznacza to, że istnieje jakiś zbiór wartości nienaruszalnych, zawsze ważnych, czy raczej to, że chcielibyśmy, aby taki zbiór istniał, bo mielibyśmy moralną płaszczyznę odniesienia? Czy jeśli taki kanon istnieje, jest on stały i ponadczasowy? Dla kogo jest on fundamentem moralności? Czy dla kultury euroatlantyckiej, czy polskiej? I wreszcie zagadnienie bodaj najtrudniejsze i na pewno najważniejsze: czy umiemy wskazać wartości, dla których jesteśmy gotowi uczynić wielki wysiłek, czy raczej poruszamy się w sferze szczerych deklaracji. Wszystkie te problemy splatają się ze sobą, co odzwierciedla się $\mathrm{w}$ obyczajach i formalnie zapisanych uzgodnieniach, ale też $\mathrm{w}$ bardzo żywiołowych dyskusjach ${ }^{8}$. Jeśli wartości są fundamentem moralnym, do którego odnoszą się nasze działania, a więc i komunikacja, powinniśmy wiedzieć, które z nich tworzą nasz kanon, które chcielibyśmy widzieć poza nim. Wartości są przede wszystkim przedmiotem dociekań filozofii (aksjologii), a także socjologii (aksjologia społeczna) - to te dziedziny nauki dają etyce słowa podstawową wiedzę o nich. Od dłuższego czasu wartościami zajmuja się również aksjolingwiści.

Jerzy Bartmiński proponuje trzy sposoby empirycznego ustalania takiego wspólnego zasobu wartości. Analizę ważnych tekstów kultury (np. wiążących dokumentów prawnych), badanie opinii społecznej oraz rekonstrukcję językowego obrazu wartości. Może się wydawać, że najbardziej konkretne jest za-

\footnotetext{
${ }^{8}$ Mam tu na myśli czarne marsze, protesty przeciw przyjmowaniu imigrantów itp.
} 
proponowane przez Jerzego Bartmińskiego odwołanie się do dokumentów Powszechnej deklaracji praw człowieka z 1948 roku, preambuły Karty praw podstawowych Unii Europejskiej z roku 2007 oraz preambuły do Konstytucji Rzeczypospolitej Polskiej, ponieważ teksty te podobne w treści wskazuja elementarne wartości europejskie - godność osoby ludzkiej, wolność, równość i solidarność (braterstwo), czyli te, do których etyka komunikacji bezpośrednio się odnosi. Zapis tych wartości był negocjowany przez gremia międzynarodowe, a bezpośredni wpływ na pierwszy z zapisów miały prace personalistów - Jacques'a Maritaina i Emmanuela Mouniera.

W gruncie rzeczy jednak dokumenty te mają charakter dość ogólnej deklaracji pewnych intencji, postulatów oraz powinności, mogą więc stanowić zaledwie początek poszukiwania kanonu. Zapis dotyczący równości i solidarności, w praktyce okazuje się nieskuteczny, o czym świadczy wprowadzenie np. innego szczegółowego prawa - o mowie nienawiści, które ma chronić równych przecież z innymi członków społeczeństwa należących do mniejszości. Gdyby był skuteczny, nowe prawo nie byłoby potrzebne. Chroni ono przed dyskredytacją, u której podłoża leży stereotyp, a taka ustawa zaprzecza idei równości. Tego rodzaju niekonsekwencji jest więcej, co pokazuje, że pewne zapisy w ważnych dokumentach są jedynie intencjonalne, postulatywne i nie dają obrazu naszego rzeczywistego stosunku do wartości.

Rekonstrukcja językowego obrazu wartości daje nam wiedzę o randze i rozumieniu niektórych wartości, ale wiedzę fragmentaryczną, bo obejmująca głównie to, co język zdążył utrwalić. Nie mówi natomiast nic o stosunku użytkowników języka do obecnych zmian miejsca wartości w ładzie społecznym, bo jest na to za wcześnie.

Badania opinii publicznej, choć też przeważnie pokazują jedynie deklaracje i niejednokrotnie ujawniają brak rozumienia wartości przez ankietowanych, są dla wiedzy o wartościach Polaków bardziej przydatne. Nie mogą to być oczywiście jedynie badania sondażowe, obejmujące 1000 czy 2000 osób, bo te nie wychwycą istotnych zależności między procesami społecznymi a zmianą w systemie/systemach wartości i nie pokażą dyferencjacji.

Uwagi te nie oznaczają oczywiście, że z zaproponowanych przez Bartmińskiego sposobów poszukiwania europejskiego kanonu wartości należy zrezygnować. Badania przez niego zaproponowane i prowadzone pokazuja polską aksjosferę i stanowią dobry punkt wyjścia refleksji aksjologicznej. W dalszym ciągu nie wiemy jednak, jak ludzie rozumieją wartości i słowa, które je określają. Wiemy jedynie, że same nazwy wartości są rozumiane bardzo różnie 
i że to może mieć wielorakie konsekwencje ${ }^{9}$. To zjawisko różnoznaczności da się zaobserwować w publikacjach o profilowaniu, a także w analizach sposobów mówienia o wartościach w mediach ${ }^{10}$.

Mamy dziś w miarę jasny obraz wartości akceptowanych, w miarę zgodny zbiór postulatów moralnych, o których ochronie w komunikacji trzeba mówić. Potrzebujemy jednak więcej szczegółowych danych uzyskanych na podstawie badań socjologicznych i to nie sondażowych, lecz szerszych, dających przede wszystkim pewniejsze rozeznanie w postawach społeczeństwa wobec wartości. Rozumienie wartości, a nawet uznanie, że są one ważne, nie oznacza jeszcze ich całkowitej akceptacji. Człowiek może uważać, że jakaś wartość jest ważna w życiu publicznym, ale nie w prywatnym, albo nie w jego życiu. Akceptacja wartości również nie musi automatycznie prowadzić do realizacji wartości. Do tego potrzebne są wola i motywacja, o czym będzie mowa w dalszej części tekstu.

Aby formułować jakiekolwiek wiarygodne tezy z zakresu etyki słowa czy aksjologii, musimy mieć obraz zachodzących w moralności zmian. Nowe zjawiska w sferze komunikacji nie są przecież czymś izolowanym, lecz wypadkową różnych i ważnych procesów społecznych. Zarówno aksjologia lingwistyczna, jak i etyka słowa powinny zatem opierać się na wynikach badań nauk społecznych - badań spójności społecznej, praktyk kulturalnych, systemów wartości, motywacji działania i innych.

Bez wątpienia bazę naukową dla etyki komunikacji stwarza socjologia (przede wszystkim socjologia moralności). Dzięki niej możemy lepiej zrozumieć pewne zjawiska, które uzewnętrzniają się w zachowaniach językowych w sposób jaskrawy i nieetyczny, a są charakterystyczne dla procesów zmieniających ład społeczny i będące jego podstawą standardy moralne.

Aby pokazać, jakie ważne są dla etyki słowa dane uzyskane dzięki badaniom społecznym, przedstawię skrótowo kilka istotnych wyników. Dla porównania zacznę od tego, co uzyskano na podstawie badań językoznawczych.

Przydatne jako punkt odniesienia dla różnych dociekań aksjologicznych są badania słów sztandarowych Walerego Pisarka. Metodologia tych badań zo-

\footnotetext{
${ }^{9}$ Przykładem są skrajne sposoby rozumienia patriotyzmu, które znajdują się w prasie. Jest on rozumiany jako gotowość oddania życia za ojczyznę i jako sprzątanie po swoim psie. Nieobecne jest natomiast jego racjonalne rozumienie jako postawy z wyboru, gotowości działania dla wspólnego dobra społeczności w danym kraju.

${ }^{10}$ Por. Profilowanie pojęć. Wybór prac, red. J. Bartmiński, Lublin: Wydawnictwo UMCS 1993; L. POLKOWSKA, Wartości i antywartości w tygodnikach opinii. Komparatywna analiza dyskursu z elementami lingwistyki kwantytatywnej, Warszawa: Wydawnictwo UKSW 2018.
} 
stała wyczerpująco przedstawiona przez Autora, więc nie trzeba jej tu omawiać. Warto jedynie wspomnieć, że próba była spora, większa niż sondażowa, obejmowała 5000 ankietowanych, a więc wyniki są miarodajne. Badanie dobrze pokazuje pojęcia pozytywne i negatywne, czyli reprezentację słowną polskich wartości i antywartości ważnych w przestrzeni medialnej i politycznej. Co prawda status słów jako reprezentantów aksjosfery został przez W. Pisarka określony arbitralnie, ale wyniki w kolejnych badaniach potwierdziły trafność wyborów autora.

W badaniach W. Pisarka wśród pierwszych dziesięciu wartości obecne są miłość, zgoda, wolność, sprawiedliwość, wiara, ojczyzna, opieka, równość, godność, naród, a jako następne pojawiają się patriotyzm, państwo, solidarność. Powtarzane kilkakrotnie badania wskazują na znaczną stabilność słów sztandarowych zwłaszcza tych z pierwszej dziesiątki. Charakterystyczne jest to, że najczęściej wybieranymi (jako miranda i kondemnanda), czyli budzącymi zainteresowanie słowami, były te odnoszące się do wartości odczuciowych - miłość, wolność, poczucie bezpieczeństwa, dopiero jako następne wybierano wartości poznawcze takie, jak nauka i prawda. Ankietowani rzadziej interesowali się wartościami moralnymi, jak sprawiedliwość, uczciwość, dobro innych, godność i transcendentnymi, jak wiara. Najrzadziej wybierali wartości obyczajowe - zgodę, tolerancję. Takie wybory można interpretować dwojako: ankietowani albo traktowali nazwy wartości dosłownie - jako hasła, albo rozumieli je jako nazwy wartości, ale nie przywiązywali wagi do tych, których nie wybierali, co może świadczyć o braku rozumienia wartości albo braku zainteresowania niektórymi wartościami. Badania W. Pisarka nie pokazały jakichś szczególnie ważnych zależności. Dwie jednak zasługują na uwagę: wykształcenie sprzyja wyborowi tolerancji, nauki, patriotyzmu i prawdy, a młodość - wyborowi tolerancji, miłości, sukcesu, piękna, luksusu. Wypada też zauważyć, że potrzebna wspólnocie solidarność pojawia się dopiero na dziesiątym miejscu. Badania słów sztandarowych są przydatne w analizach dyskursu medialnego - pomagają go analizować pod względem politycznym oraz ideologicznym. Nie oddają natomiast rzeczywistego nastawienia społeczeństwa do wartości.

Okazuje się, że w badaniach spójności społecznej regularnie prowadzonych przez GUS ${ }^{11}$ oraz badaniach praktyk kulturalnych Polaków ${ }^{12}$ przeprowadzo-

\footnotetext{
${ }^{11}$ Jakość życia w Polsce w 2015 r. Wyniki badania spójności społecznej, Studia i analizy statystyczne, Warszawa 2017.

12 R. Drozdowski, B. Fatyga, M. Filiciak, M. Krajewski, T. SZlendak, Praktyki kulturalne Polaków, Toruń: Wydawnictwo Naukowe Uniwersytetu Mikołaja Kopernika 2014.
} 
nych kilkanaście lat później niż badanie słów sztandarowych pojawiają się nieco inne zestawy wartości niż $w$ badaniach Pisarka ${ }^{13}$. Lektura wyników tych badań pokazujących stosunek Polaków do wartości i jego związek z kapitałem społecznym nie nastraja jednak optymistycznie.

Ankietowani przez GUS w 2015 roku za najważniejsze wartości uznali zdrowie, rodzinę i szczęście rodzinne, uczciwość, poczucie stabilizacji, poczucie bycia potrzebnym, szacunek innych ludzi, miłość, sprawność fizyczną, przyjaźń, pracę zawodową i pieniądze. W następnej grupie ważnych wartości znalazły się patriotyzm, wykształcenie i dążenie do wiedzy, wolność głoszenia własnych poglądów, wiara, kariera, własne zainteresowania i hobby, kariera, rozrywka i życie pełne przygód.

Badania GUS przeprowadzane są regularnie i na dużej próbie, co pozwala lepiej wskazać wpływ różnych czynników na przyznawanie określonej rangi poszczególnym wartościom. Zasadniczo wszyscy uznają, że ważne są zdrowie, rodzina i szczęście rodzinne. Analizy przekrojowe pokazały, że wybór następnych z najważniejszych wartości, tzn. miłości, uczciwości, poczucia stabilizacji i pieniędzy był zależny od płci, wieku i wyksztalcenia ${ }^{14}$.

Dla ludzi w przedziale wiekowym od 16 do 34 roku życia uczciwość jest mniej ważna niż dla osób powyżej 34 roku życia. Ważniejsza jest także dla ludzi wykształconych. Patriotyzm i dobro ojczyzny bardziej cenią najmłodsi (między 16 a 24 rokiem życia) i najstarsi (po 75 roku życia). Z wiekiem spada też waga miłości jako najważniejszej wartości w życiu. Poczucie stabilizacji najważniejsze było dla ludzi w wieku od 35 do 44 lat i dla lepiej wykształconych. Pieniądze ważniejsze były dla ludzi o niskim statusie materialnym, mających niskie wykształcenie i młodych. Poczucie stabilizacji najbardziej ceniły osoby lepiej wykształcone w wieku od 35 do 44 lat. Zarówno w młodszych, jak i starszych grupach wiekowych szansa na pojawienie się tej wartości wśród najważniejszych zmniejszała się.

Badanie GUS-u pokazało ponadto, że wolność głoszenia poglądów jest bardzo ważna dla ludzi młodych (dla 73\%), a waga jej spada $\mathrm{z}$ wiekiem. Młode pokolenie charakteryzuje się indywidualistycznym podejściem do życia, przykłada wagę do samorozwoju i wolności słowa, a religia ma w jego życiu niewielkie znaczenie. Dało się jednak zauważyć, że jeżeli badani byli

\footnotetext{
${ }^{13}$ Pisarek badał słowa. Część z nich to nazwy wartości, część - obiekty wartościowania.

${ }^{14}$ Kobiety na trzecim miejscu wymieniały miłość, mężczyźni - pieniądze, na czwartym miejscu kobiety lokowały uczciwość, a mężczyźni - pracę zawodową, na piątym kobiety poczucie stabilizacji, mężczyźni - miłość.
} 
zaangażowani religijne, wiązało się to $\mathrm{z}$ wyborem przez nich uczciwości i patriotyzmu jako wartości bardzo ważnych i ważnych.

Badanie GUS-u objęło również postawy mieszkańców Polski wobec wybranych kontrowersyjnych zachowań społecznych, czyli sprawdzało deklaracje moralności w sferze społecznej i obywatelskiej. Wykazało, że najmniej akceptowane były przede wszystkim: przyjmowanie i wręczanie łapówek oraz pobieranie zasiłków przez osoby do tego nieuprawnione $(82,7 \%)$, nieudzielenie pomocy osobie poszkodowanej lub potrzebującej pomocy $(73,1 \%)$ oraz wykorzystywanie stanowiska służbowego dla własnych korzyści $(72,6 \%)$, a także zatrzymywania dla siebie omyłkowo wydanej reszty $(70,8 \%)$ oraz pozostawiania śmieci w miejscu publicznym $(69,5 \%)$ (jeśli w pobliżu nie było kosza). Spośród uwzględnionych w badaniu zachowań, z największym przyzwoleniem spotykały się: podejmowanie nielegalnego zatrudnienia, świadome kupowanie rzeczy podrobionych i fałszywych oraz ściaganie na egzaminach. Na ogół większą akceptacją wobec analizowanych zachowań naruszających normy społeczne charakteryzowali się mężczyźni niż kobiety, a także osoby młode.

Badanie pokazało interesujące zjawisko: $\mathrm{z}$ jednej strony ujawniła się wyraźna tendencja indywidualistyczna - badani za najważniejsze uznali wartości ważne w prywatnym życiu, z drugiej - przynajmniej zadeklarowali wyższy poziom rygoryzmu w sferze moralności obywatelskiej i społecznej w stosunku do 2008 roku, kiedy to przeprowadzano badania przemian moralności w Polsce i Europie. Przykładowo - brak akceptacji dla jazdy bez biletu publicznymi środkami lokomocji wzrósł o $12 \%$, a dla posługiwania się łapówkami o $25 \%$.

Dalsza część badań GUS oraz badania praktyk kulturalnych ujawnia jednak dość niepokojące właściwości polskiego życia społecznego. Polacy ograniczają kontakty społeczne do najbliższej rodziny, relacje z osobami spoza niej są rzadkie i maleją $\mathrm{z}$ wiekiem. Ważna $\mathrm{w}$ sferze deklaracji religia nie ma właściwie funkcji wspólnototwórczej, bo aktywność ludzi w tej sferze maleje. Następuje także wyraźna marginalizacja wspólnot sąsiedzkich, których nie spajają działania zespołowe dla gminy, dzielnicy, osiedla itp., wzajemna pomoc w codziennym życiu czy praktyki religijne. Drugi człowiek nie jest potrzebny na co dzień, ufamy mu niejako z konieczności i nie prosimy go o pomoc, a jeśli to czynimy, to wtedy, gdy nie mamy płatnych fachowców. Przestaje być uczestnikiem naszego życia, towarzyszem wspólnego losu, pozostaje co najwyżej jego świadkiem. Badacze pokazują wyraźnie, że brak samoorganizacji, niskie zaangażowanie w działania dla dobra wspólnego źle wpływają na poziom kapitału społecznego. Dane pokazują, że aż 80\% Polaków nie angażowało się w żadnych organizacjach lub angażowało społecznie tylko incydentalnie. 
Badanie spójności społecznej uwidacznia, że w Polsce mamy do czynienia z niskim poziomem i małym rozpowszechnieniem kapitału stowarzyszeniowego oraz stosunkowo wysokim poziomem kapitału nieformalnego, przede wszystkim kapitału rodzinnego i - w mniejszym stopniu - kapitału towarzysko-sąsiedzkiego. Wysokimi zasobami wszystkich trzech rodzajów kapitału (stowarzyszeniowego, towarzysko-sąsiedzkiegoirodzinnego) charakteryzowała się nie więcej niż jedna na sto osób w wieku powyżej 16 lat.

Zjawisko niskiego kapitału społecznego jest związane z niskim poziomem zaufania społecznego. Największym zaufaniem cieszyły się w 2015 roku służby ratunkowe (straż pożarna 94\%, pogotowie ratunkowe 84\%), a tylko nieco mniejszym - wojsko, policja i Kościół Rzymskokatolicki (67\%). Około połowy mieszkańców Polski miało zaufanie do sądów i władz lokalnych, a mniej więcej jedna czwarta osób ufała instytucjom władzy ustawodawczej oraz rządowi.

Jak widać, w polskim społeczeństwie silnie zaznaczają się tendencje indywidualistyczne - ludzie, zwłaszcza młodzi są skupieni na sobie i swojej rodzinie. Charakterystyczne jest, że ważne w badaniach W. Pisarka takie wartości, jak godność, sprawiedliwość, zgoda, solidarność w ogóle nie pojawiły się we wskazaniach ankietowanych przez GUS. W obu badaniach socjologicznych wskazywano szacunek jako wartość pożądaną, ale nie miał on statusu wartości bardzo ważnej.

Publikacja powstała jako wynik badania praktyk kulturalnych, przedstawia diagnozę jeszcze bardziej przygnębiającą - rozsypanej wspólnoty i braku społeczeństwa. Nie dość, że potwierdza tezę o niskim kapitale sieciowym, ale dowodzi wsobności relacji społecznych, braku wysokich kompetencji kulturowych, braku innowacyjności społecznej, destrukcji norm powinnościowych i bałaganu aksjologicznego. De facto oznacza to, że nie ma ładu w przestrzeni społecznej, bo brakuje wspólnych wartości, norm i znaczeń, a systemy moralne zwłaszcza młodego pokolenia Polaków przyjęły, jak pisze Tomasz Szlendak, postać hybrydalną. Prywatyzacja wartości sprawiła, że ludzi łączą nie systemy moralne, lecz głównie style życia. Nie pozostają one jednak w żadnym związku z systemem wartości. Zjawisko to T. Szlendak określił mianem indywidualizmu egosekurialnego. Pocieszające jest może to, że to praca staje się często stylem życia, a jej nie da się tak po prostu dowolnie zmieniać, więc może być ważnym punktem odniesienia dla różnych działań moralizacyjnych.

Przedstawione tu wyniki badań społecznych pokazują dość niepokojące zjawisko wzrostu wagi norm samorealizacji i braku zainteresowania normami prospołecznymi. Wydaje mi się, że można je przynajmniej częściowo wyjaśnić niestabilnością społeczeństwa epoki przemian. 
Skupienie się człowieka na rodzinie, pracy zawodowej, wybór własnego stylu życia wydaje się zapewne gwarancją bezpieczeństwa i możliwości realizacji własnej biografii. Społeczeństwo niestabilne, zmieniające od kilkudziesięciu lat swój ład moralny takiej gwarancji nie daje, zwłaszcza że prowadzi ono nieustanny spór aksjologiczny, w którym obserwujemy nienaturalną podaż wartości. Pozbawiony wskazówek etycznych człowiek tworzy więc własny zbiór, zapewniający mu spokój i skuteczność działania.

Trzeba teraz zapytać o to, co z zarysowanego tu na podstawie badań socjologów obrazu wynika dla etyki słowa. Po pierwsze - rzucają one światło na wybory wartości i uwarunkowania tych wyborów. Po drugie - ułatwiaja poznanie postaw społecznych wobec wartości i celów życiowych.

Otóż jeśli chcemy wpłynąć na zmianę norm w sferze społecznej lub ich respektowanie - skłonić ludzi do poszanowania godności każdego człowieka, a wiemy, jakie postawy przeważają w społeczeństwie, musimy odwołać się do wartości należących do tej sfery życia, która jest dla ludzi najważniejsza. Sposób przekazu treści dotyczących norm etycznych musi być uzależniony od potrzeb i postaw odbiorcy tych treści.

Z badań wynika, że najważniejsze sfery życia to rodzina, krąg przyjaciół i praca. W obu tych obszarach ludzkiej aktywności normy komunikacji etycznej są ważne. Można zatem z pewnością mówić o nich jako o tworzących i podtrzymujących wspólnotę rodzinną i wspólnotę ludzi razem pracujących, a o respektowaniu zasad jako o sposobie pozyskiwania szacunku i zaufania (na tym zależało większości ankietowanych).

Badania postaw wobec wartości dają oczywiście tylko wiedzę o deklaracjach, ale jeśli jest ona uzupełniona wiedzą o celach życiowych, to odwołanie się do motywacji, które kierują postępowaniem ludzi w relacjach społecznych oraz praw, których dla siebie żąda jednostka lub grupa, może okazać się skuteczne. Badania pokazują, że rzadko może to być motywacja prospołeczna, bo w społeczeństwie przeważaja postawy indywidualistyczne. Wiemy jednak, że ważny jest dla ludzi szacunek i chcą na niego zasługiwać, chcą też zapewne, aby szacunek miała ich rodzina. A zatem możemy się odwołać do motywacji godnościowej, która dla ludzi skupionych na własnych sprawach jest zapewne ważniejsza niż motywacja troski i współczucia. Drugim rodzajem motywacji, do której odwołanie powinno być skuteczne, jest motywacja wzajemnościowa. Własna godność jest ważna dla wszystkich ludzi, więc odwołanie się do jej poszanowania okazywanego niejako w reakcji zwrotnej, wydaje się zasadne.

W pierwszym wypadku do posłuszeństwa normie skłania szacunek dla człowieka, a uczuciem, które stanowi sankcję za niezachowanie tej normy, 
jest wstyd (jako komponent wyrzutów sumienia). W drugim wypadku (motywacji wzajemnościowej) do zachowania normy skłania chęć uzyskania potwierdzenia szacunku ze strony drugiej osoby, a uczucie, które budzi się na skutek złamania normy - to zapewne wstyd z powodu stygmatu, opinii osoby nieumiejącej się zachować, nieznającej reguł społecznych.

Dzięki przywołanym tu badaniom społecznym możemy określić możliwości zmian postawy wobec nieetycznej komunikacji. Słabnie pobłażliwość dla niemoralności w sferze obywatelskiej i społecznej, co oznacza, że mimo relatywizacji zasad moralnych zaczynamy stawiać wymagania członkom społeczeństwa i przystajemy na to, by przestrzegania zasad wymagano od nas. Zapewne proces wzrostu rygoryzmu obejmie także komunikację, bo bez braku zaufania trudno jest funkcjonować instytucjom publicznym. Już teraz opinia publiczna jest wrażliwa na kłamstwo w sferze publicznej. Wydaje mi się, że egzekwowanie zachowania zgodnego z normami społecznymi jest w polskim społeczeństwie trudne i w związku z tym potrzebne są bardziej szczegółowe informacje o tym, na czym można by się oprzeć. Jeśli jednak widzimy wyraźną tendencję do rygoryzmu w sferze obywatelskiej i społecznej, możemy domagać się lepszego przestrzegania zasad etycznej komunikacji właśnie w przestrzeni publicznej - w polityce i mediach, bo będzie to zgodne $\mathrm{z}$ budzącymi się potrzebami społecznymi. (Wzrost permisywizmu nastąpił wyłącznie w prywatnej sferze życia.)

Należałoby również wykorzystać ważną informację uzyskaną dzięki badaniom spójności społecznej - młodzi ludzie w wieku szkolnym nie cenią uczciwości, ale potrzebują wolności wypowiadania poglądów. Wiemy też, że bywają okrutni dla swoich kolegów i to właśnie język jest narzędziem poniżania, stygmatyzacji i marginalizacji ofiar. To ważna wskazówka dla dydaktyków - naukę etyki i komunikacji etycznej należy rozpocząć na etapie edukacji wczesnoszkolnej.

Na zakończenie rozważań o naukowych podstawach etyki słowa chciałabym jeszcze krótko wspomnieć o wkładzie kilku dyscyplin naukowych językoznawstwa, retoryki i medioznawstwa w tę dziedzinę nauki. Badania wartości, słownictwa etycznego, problematyki prawdy i kłamstwa, manipulacji, analiza dyskursu, prace dotyczące języka mediów i języka polityki - to główny nurt dociekań etycznych ${ }^{15}$. Szeroko rozumiane językoznawstwo daje przede wszystkim narzędzia analizy i opisu nietycznego i etycznego użycia

\footnotetext{
${ }^{15}$ Dorobek z tego zakresu omówiła Zofia CYGAL-KRUPA w tekście Etyka stowa we wspótczesnych badaniach językoznawczych, w: Świat stów. Jedność w różności, red. M. Pachowicz, K. Choińska, Tarnów: Państwowa Wyższa Szkoła Zawodowa w Tarnowie 2016, s. 261-269.
} 
słowa, retoryka i analiza dyskursu pokazują wpływ różnych nieetycznych zabiegów (np. argumentacyjnych) na myślenie i zachowania użytkowników języka, podpowiadają możliwości interpretacji i wskazują kryteria oceny wypowiedzi. Retorykom zawdzięczamy cenne prace o debatach i możliwościach porozumienia w sporach, a politologowi (Mirosławowi Karwatowi) opis zjawiska nagonki, perfidii, manipulacji oraz dyskredytacji. Ogromne znaczenie dla etyki słowa mają prace dotyczące konstruowania narracji zarówno psychologiczne, jak i medioznawcze. Nie bez znaczenia dla myśli o etycznej komunikacji są również studia prakseologiczne, traktujące o metodach wywierania wpływu społecznego i sterowania ludzkimi zachowaniami. Prace te podejmuja problem stosowania perswazji, przymusu, przemocy, posługiwania się podstępem, używania metod terrorystycznych ${ }^{16}$.

W naszej wiedzy o etyce komunikacji dają się jeszcze odczuć pewne braki - nie mamy dobrych narzędzi badania sposobów rozumienia wartości, nie wiemy jeszcze, co z tego rozumienia wynika dla postępowania człowieka i jak skutecznie wpływać na motywację moralnego działania słowem.

Dla etyki komunikacji ważne jest bowiem nie tylko to, jakie są możliwe rozumienia nazw typu wolność, szacunek, uczciwość, tolerancja, lecz także to, jak użytkownik języka pojmuje realizację wartości przez nie określanych oraz jaka motywacja może sprawić, że człowiek podejmie się trudu życia według wartości. Psychologia wiele lat zajmowała się budzeniem potrzeb, będących podstawą decyzji o zakupie jakiegoś produktu, programowaniem życia jednostki, realizacją celów indywidualnych. Nie zajmowała się jednak motywacją postępowania moralnego. To dotkliwa luka w naszej wiedzy, którą tylko w niewielkim stopniu wypełniaja prace filozoficzne.

Etyka słowa rozwinęła się w sytuacji powszechnego zaniechania myślenia podmiotowego, zaniechania, które prowadzi do dehumanizacji człowieka i zaniku postaw prospołecznych, do prymitywnego nadawania ważności zadaniom, a nie ludziom. Ta sytuacja stawia przed etyką słowa misję kształtowania komunikacji opartej na poszanowaniu człowieka i pomocnej w budowaniu ładu moralnego wypracowanemu dzięki porozumieniu i uzgodnieniom, a nie w wyniku walki grup interesów. Do tego potrzebuje zaangażowania przedstawicieli różnych dyscyplin humanistycznych.

\footnotetext{
${ }^{16} \mathrm{~W}$ tym artykule nie sposób omówić wszystkich związków etyki komunikacji z innymi dziedzinami nauki. Stałby się on bowiem zbyt obszernym studium. Szczegółowe rozważania na temat interdyscyplinarności etyki komunikacji zamieszczam w tomie „Etyka komunikacji”, nad którym obecnie pracuję.
} 


\title{
BIBLIOGRAFIA
}

BARTMIŃSKI J.: Etyka słowa a potoczny wzorzec komunikacji, w: Oblicza polszczyzny, red. A. Markowski, R. Pawelec, Warszawa: Narodowe Centrum Kultury 2012.

CEgIEŁA A.: Słowa i ludzie. Wprowadzenie do etyki słowa, Warszawa: Elipsa 2014.

CYGAL-KRUPA Z.: Etyka słowa we współczesnych badaniach językoznawczych, w: Świat słów. Jedność w różności, red. M. Pachowicz, K. Choińska, Tarnów: Państwowa Wyższa Szkoła Zawodowa w Tarnowie 2016, s. 261-269.

Drozdowski R., Fatyga B., Filiciak M., Krajewski M., Szlendak T.: Praktyki kulturalne Polaków, Toruń: Wydawnictwo Naukowe Uniwersytetu Mikołaja Kopernika 2014.

Jakość życia w Polsce w 2015 r. Wyniki badania spójności społecznej, Studia i analizy statystyczne, Warszawa 2017.

MARITAIN J.: Humanizm integralny, Warszawa: Wydawnictwo Krąg 1981.

OssowsKa M.: Socjologia moralności, Warszawa: Wydawnictwo Naukowe PWN 2005.

POLKOWSKA L.: Wartości i antywartości w tygodnikach opinii. Komparatywna analiza dyskursu z elementami lingwistyki kwantytatywnej, Warszawa: Wydawnictwo UKSW 2018.

SzTOMPKA P.: Socjologia. Analiza społeczeństwa, Kraków: Wydawnictwo Plus 2012.

TISChNER J.: Myślenie według wartości, Kraków: Wydawnictwo Znak 1993.

Tugendahat E.: Wykłady o etyce, przeł. J. Sidorek, Warszawa: Oficyna Naukowa 2004.

TYSZKA A.: Aksjologia społeczna. Między PRL a IV RP, Warszawa: Oficyna Wydawnicza Volumen 2016.

\section{NA JAKICH PODSTAWACH NAUKOWYCH OPIERA SIĘ ETYKA SŁOWA?}

\author{
S t r e s z c z e n i e
}

Etyka słowa jest nauką interdyscyplinarną. Opiera się na założeniu personalistycznej koncepcji człowieka, z której wynika nakaz poszanowania partnera komunikacji. Socjologia dostarcza etyce danych o postawach wobec wartości, motywacjach postępowania oraz zmianach moralności. Metodologia badań etyki słowa zaczerpnięta jest z szeroko rozumianego językoznawstwa oraz retoryki. Celem etyki słowa jako działalności jest kształtowanie takiej komunikacji, która prowadzi do porozumienia.

Słowa kluczowe: osoba; podmiotowość; wartość; postawa; motywacja moralna; etyka komunikacji. 


\title{
ON WHAT SCIENTIFIC BASIS IS THE ETHICS OF THE WORD BASED?
}

\author{
$\mathrm{S} \mathrm{u} \mathrm{m} \mathrm{m} \mathrm{a} \mathrm{r} \mathrm{y}$
}

Speech Ethics is an interdisciplinary research discipline. It is founded on the personalistic concept of a human being, which implies the obligation to respect the communication partner. Sociology provides ethics with data on attitudes towards values, motivations for behaviour and changes in morality. The research methodology in Speech Ethics is derived from the broadly understood linguistics and rhetoric. The pragmatic aim of Speech Ethics is to shape communication patterns that lead to mutual understanding.

Key words: human person; subjectivity; value; attitude; moral motivation; communication ethics. 